\title{
PERSYARATAN PERIZINAN LINGKUNGAN DAN ARTI PENTINGNYA BAGI UPAYA PENGELOLAAN LINGKUNGAN DI INDONESIA
}

\author{
Suparto Wijoyo \\ Fakultas Hukum Universitas Airlangga, suparto_wijoyo@yahoo.com
}

\begin{abstract}
The functional meaning of environmental license in order to manage environment can be seen on the precision or exactness of fulfillment of conditions of environmental license which administratively is relevant for environmental protection. The conditions, that must be met to hold environmental license, have important meaning to evaluate environmental management conducted by corporation. Conditions of environmental license as inserted in document of license are direction that must be followed by the holder of license. Government institutions which have competence to give license should formulate all aspects of operation of industrial activity in the form environmental license.
\end{abstract}

Keywords: environmental licence, environmental protection, environmental management.

\begin{abstract}
Abstrak
Makna fungsional izin lingkungan dalam upaya pengelolaan lingkungan hidup tercermin pada ketepatan atau kepastian pada pemenuhan persyaratan izin lingkungan, yang secara administratif relevan untuk memberikan perlindungan lingkungan. Persyaratanpersyaratan yang harus dipenuhi untuk memperoleh izin lingkungan memiliki arti penting untuk mengevaluasi pengelolaan lingkungan yang dilakukan oleh suatu perusahaan. Persyaratan-persyaratan sebagaimana disertakan dalam dokumen perizinan menjadi arahan yang harus dipatuhi bagi pemegang izin. Lembaga pemerintah yang memiliki kewenangan untuk menerbitkan izin harus memformulasikan seluruh aspek operasional kegiatan industri dalam bentuk izin lingkungan.
\end{abstract}

Kata Kunci : izin lingkungan, pengelolaan lingkungan dan perlindungan lingkungan

\section{Pendahuluan}

Makna fungsional izin lingkungan dalam upaya pengelolaan lingkungan hidup tercermin pada ketepatan penuangan persyaratan perizinan yang secara administratif sangat relevan bagi perlindungan lingkungan:
Therearemanycaseswhereenforcement of general environmental regulations and standards, alone, is insufficient to effectively protect the environment. In these case, it is useful for additional and site specific environmental control conditions to be applied throughout 
the period of continuing operations. This can be done by attaching relevant conditions specific to the particular operation to the environmental protection of pollution control licence for that operation, and the enforcement of those conditions. ${ }^{1}$

Melalui persyaratan perizinan itulah instrumen perizinan lingkungan memiliki arti penting dalam rangka pencegahan pencemaran lingkungan maupun untuk menilai kinerja pengelolaan lingkungan suatu perusahaan:

An environmental protection licence is a tool that an environmental agency can use to impose conditions on the operations of a particular premise or site to strengthen its environmental management and performance. It is a licence to operate and to control pollution (not a "licence to pollute"), subject to a number of site specific conditions. The licence conditions control the actual or potential environmental impacts from the site. ${ }^{2}$

Persyaratan perizinan lingkungan yang tertuang dalam dokumen izin adalah arahan yang wajib ditaati para pemegang izin. Instansi yang berwenang menerbitkan izin lingkungan merumuskan semua aspek operasional kegiatan industri dalam format izin lingkungan.

Penuangan persyaratan perizinan

\footnotetext{
1 Warwick Forrest, Manual for Environmental Law Enforcement and Casework, Project Report No. 54, h. 19. (Bapedal Jawa Timur)

${ }^{2}$ Ibid.
}

lingkungan harus dilakukan secara cermat dan berhati-hati. Izin lingkungan yang diterbitkan tidak mengenai sasaran untuk kepentingan perlindungan lingkungan (lingkungan) apabila persyaratan perizinan yang diperlukan tidak dituangkan secara spesifik, tegas, tepat, terarah, terukur serta dapat diimplementasikan. ${ }^{3}$

Izin lingkungan dan persyaratannya harus dibuat berdasarkan ukuran-ukuran yuridis yang memperhitungkan keadaan individual kegiatan industri yang memiliki dampak pada langkah-langkah pengelolaan lingkunganhidup. Kemampuaninstansiyang berwenang menerbitkan izin lingkungan untuk menetapkan persyaratan perizinan akan mempengaruhi dan menentukan tingkat keberhasilan pengelolaan lingkungan hidup serta menjadi faktor penting bagi pengembangan "legal instruments of environmental policy”. ${ }^{4}$

\section{Pembidangan Persyaratan Perizinan Lingkungan}

Terdapat pembidangan persyaratan perizinan lingkungan yang mengakomodasi segala bentuk komponen dasar perlindungan lingkungan, yaitu:

a. persyaratan standar ("standard

${ }^{3}$ Ibid., h. 17 dan 20. Badan Pengendalian Dampak Lingkungan (Bapedal) and East Java Pollution Control Implementation (PCI) Project, Manual for Environmental Law Enforcement and Casework, Project Report No. 54, December 1998. Laporan ini merupakan hasil penelitian bersama dari "A Project Managed on Behalf of the Government of Indonesia and the Australia Agency for International Development (AusAID) by the CSS Joint Venture: CMPS\&F - CINCLAIR KNIGHT MERZ - SAGRIC".

${ }^{4}$ G.H. Addink, Penataran Environmental ... op.cit., h. 29-68. Th.G. Drupsteen dan L. Woltgens, op.cit., h. 30. 
conditions")

b. persyaratan batas ("limit conditions")

c. persyaratan operasi ("operating conditions")

d. persyaratan pemantauan("monitoring conditions"), dan

e. persyaratan pelaporan ("reporting conditions"). ${ }^{5}$

Persyaratan standar ("standard conditions") berisikan penegasan bahwa pemegang izin lingkungan diharuskan untuk: mentaati peraturan perundang-undangan dan baku mutu lingkungan yang relevan, memelihara sarana teknis pengelolaan lingkungan hidup, serta menginformasikan kepada instansi pemberi izin mengenai emisi yang melebihi baku mutu. ${ }^{6}$

Persyaratan batas ("limit conditions") perizinan lingkungan memuat perincian daftar bahan pencemar yang perlu mendapat perhatian dan beban masing-masing konsentrasi "pollutants". Penerapan pembatasan dilakukan berdasarkan tingkat buangan emisi yang berasal dari sumber pencemaran (industri). ${ }^{7}$

Persyaratan operasi ("operating conditions") berkaitan dengan lokasi dan kegiatan industri. Persyaratan ini dimaksudkan untuk memastikan bahwa instalasi industri yang didirikan hanya mempunyai risiko yang kecil atau tidak mencemarkan lingkungan. Dalam

\footnotetext{
5 Warwick Forrest, loc.cit.

6 Ibid., h. 20.

7 Ibid., h. 21 The U.S. Environmental Protection Agency, RCRA Orientation Manual, Office of Solid Waste/Communications, Information, and Resources Management Division, Washington, D.C., 1998, h. 123137.
}

persyaratan pemantauan ("monitoring conditions") termuat kewajiban perusahaan untuk melakukan monitoring internal terhadap semua emisi. Hasil pemantauan diinformasikan secara terbuka dan dapat menjadi indikator kehandalan kinerja industri yang bersangkutan dalam melakukan pengelolaan lingkungan hidup. Ditekankan bahwa:

\section{The monitoring conditions of a} pollution control should stipulate:

- the specific discharge/emission streams to be monitored;

- the location points at which monitoring is to occur;

- eachofthe pollutants and parameters to be monitored;

- the levels of precision required;

- the nature and frequency of monitoring. ${ }^{8}$

Persyaratan pelaporan ("reporting conditions") merupakan fase lanjutan dari persyaratan pemantauan yang menekankan pada kegiatan untuk melaporkan hasil pemantauan kepada badan pengelola lingkungan dan masyarakat. Dari persyaratan pelaporan dapat diketahui tingkat penaatan industri terhadap keseluruhan persyaratan perizinan lingkungan. ${ }^{9}$

Persyaratan perizinan lingkungan tersebut pada dasarnya dapat disederhanakan secara kategoris dalam: persyaratan

\footnotetext{
${ }^{8}$ Ibid., h. 21-22.

9 Ibid., h. 23. Sehubungan dengan pembahasan ini, sebagai bahan perbandingan dapat dibaca pula Direktoral Pengendalian Pencemaran Air dan Laut Badan Pengendalian Dampak Lingkungan (Bapedal) dan Pollution Control Implementation (PCI), Bahan Pendukung Lokakarya Perizinan Buangan Limbah Cair, Bandung, 30-31 Maret 1999, h. 55-58.
} 
prosedural ("procedural conditions"), persyaratan substansial ("substantial conditions") dan persyaratan evaluatif ("evaluation conditions"). Persyaratan prosedural menyangkut identitas perusahaan yang termanifestasi dalam "application form” izin lingkungan. Persyaratan substansial berkaitan dengan kewajiban yang harus dilaksanakan pemegang izin dalam menjalankan instalasi sebagaimana terangkum dalam persyaratan standar dan persyaratan batas. Persyaratan evaluatif merupakan tindak lanjut yang harus dilakukan pemegang izin (pengawasan internal) maupun instansi yang berwenang (pengawasan eksternal) dalam menilai tingkat ketaatan penanggung jawab instalasi. Komponen persyaratan evaluatif direfleksikan dalam persyaratan pemantauan dan persyaratan pelaporan.

Esensiketigajenis persyaratan perizinan lingkungan termaksud (persyaratan prosedural, persyaratan substansial dan persyaratan evaluatif) dapat digambarkan dalam tabel berikut:

\section{Esensi Persyaratan Perizinan Lingkungan}

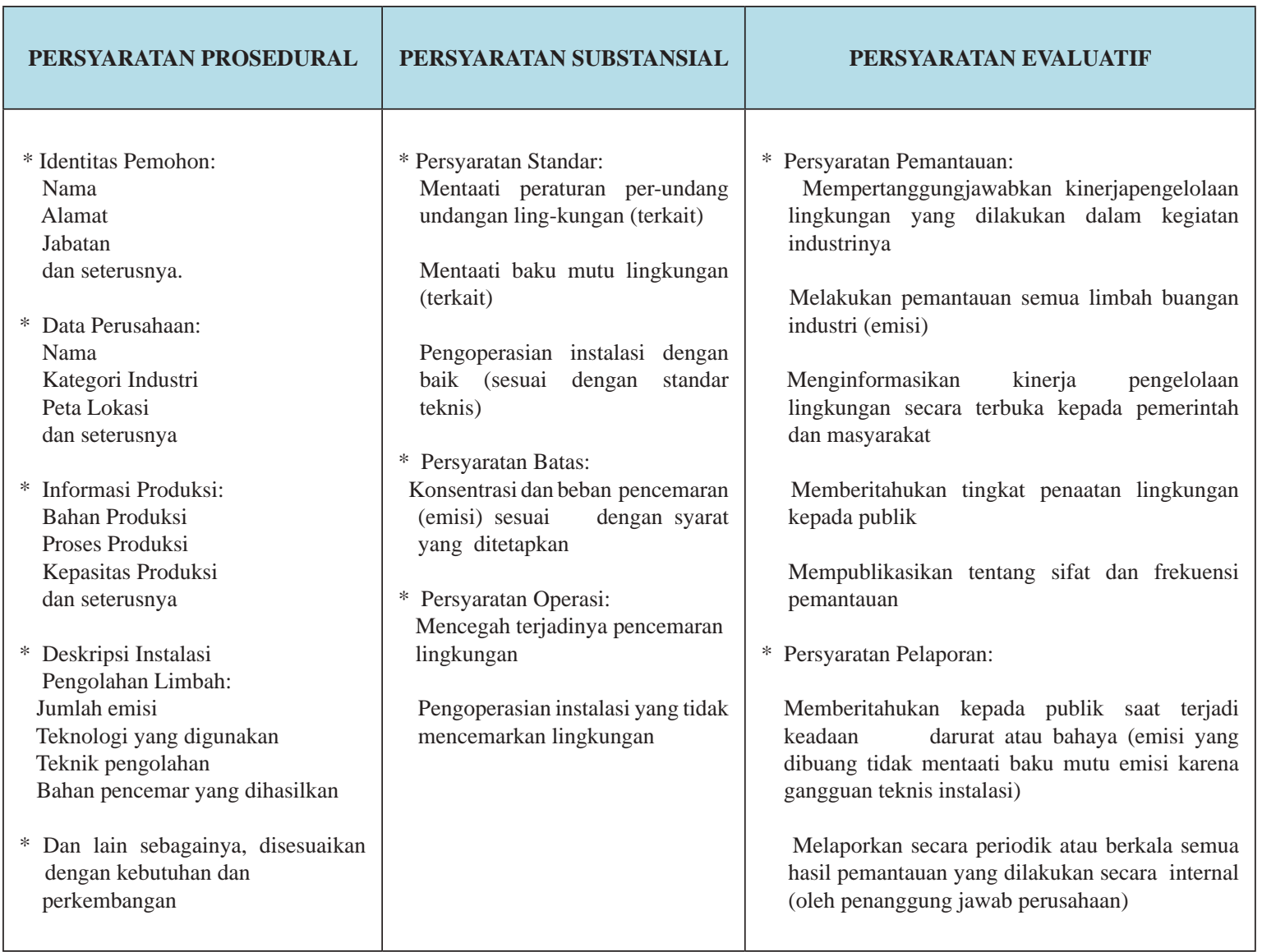

Tabel 1.

Persyaratan prosedural, substansial dan evaluatif merupakan kesatuan yuridis administratif dalam tatanan perizinan lingkungan. Elemen persyaratan prosedural menginformasikan tentang identitas pemohon izin secara individual maupun institusional 
kepadainstansi yangberwenang menerbitkan izin lingkungan. Lingkup persyaratan substansial menunjukkan beragam kewajiban yang harus dilakukan pemegang izin lingkungan. Komponen persyaratan evaluatif digunakan untuk menilai tingkat penaatan internal dan eksternal pemegang izin lingkungan terhadap persyaratan susbtansial yang ditetapkan instansi yang berwenang di bidang perizinan lingkungan.

Dari persyaratan evaluatif dapat diketahui kinerja pengelolaan lingkungan pemegang izin dalam mengimplementasikan izin lingkungan.

\section{Contoh Persyaratan Prosedural Izin HO,} Izin Usaha Industri, Izin Pembuangan Limbah ke Media Lingkungan (IPLM) dan Izin Lokasi

Materi persyaratan prosedural Izin $\mathrm{HO}$, Izin Usaha Industri, IPLM dan Izin Lokasi ternyata tidak sama. Persyaratan prosedural Izin HO dapat ditelusuri pada Pasal 4 HO:

Bij het verzoek van vergunning wordt een nauwkeurige omschrijving, zoo noodig toegelicht door nauwkeurige teekeningen, overgelegd van de plaats, waar de inrichting zal worden opgericht, zoomede van de daarbij te bezigen machinerijen, werktuigen en hulpmiddelen en van hun plaatsing in de inrichting, benevens een opgave van het geen in de inrichting zal worden verricht, vervaardigd, verzameld of bewaard. ${ }^{10}$

${ }_{10}$ Terjemahan bebas Pasal 4 HO: Permohonan untuk mendapatkan izin harus dilampiri dengan keterangan yang seksama, jika perlu dijelaskan pula dengan gambar yang rinci tentang lokasi di mana instalasi itu akan didirikan,
Ketentuan Pasal 4 HO telah dijabarkan dalam Pasal 7 Peraturan Menteri Dalam Negeri No. 7 Tahun 1993 tentang Izin Mendirikan Bangunan dan Izin Undangundang Gangguan Bagi Perusahaan Industri (Permendagri No. 7 Tahun 1993).

Persyaratan prosedural Izin Usaha Industri tidak diatur dalam UU Perindustrian maupun PP No. 13 Tahun 1995. Persyaratan prosedural Izin Usaha Industri terdapat dalam Keputusan Menperindag No. 590 Tahun 1999 dan Keputusan Menteri Negara Penggerak Dana Investasi/Ketua Badan Koordinasi Penanaman Modal No. 126/I/ Industri/1995 tentang Pemberian Izin Usaha Industri (Keputusan Menteri Negara Penggerak Dana Investasi/Ketua BKPM No. 126 Tahun 1995).

Permohonan Izin Usaha Industri dilakukan dengan mengisi Formulir Isian Izin Usaha Industri yang mencakup uraian mengenai: (i) "identitas perusahaan" (nama perusahaan, alamat kantor, nomor pokok wajib pajak [NPWP], nama pimpinan, dan lokasi pabrik), serta (ii) "informasi rencana kegiatan industri" (lahan, produksi, bahan baku, jenis peralatan, proses produksi, jumlah investasi serta jumlah tenaga kerja (domestik maupun asing). ${ }^{11}$

begitu juga tentang mesin-mesin yang digunakan dan alat-alat bantu (perkakas-perkakas) yang diperlukan dan tentang tempatnya di dalam instalasi, demikian pula suatu keterangan tentang segala sesuatu yang akan dikerjakan, dibuat, dikumpulkan atau disimpan dalam instalasi (bangunan tempat usaha) itu". Terjemahan ini dapat bandingkan dengan John Salindeho, Undang-undang Gangguan dan Masalah Lingkungan, Sinar Grafika, Jakarta, 1993, h. 173.

${ }^{11}$ Kutipan ini dimodifikasi sesuai dengan kebutuhan penulisan Disertasi ini tanpa mengurangi substansi Formulir Isian Izin Usaha Industri. Untuk perbandingan dapat dibaca dalam Departemen Perindustrian Kantor Wilayah Departemen Perindustrian Propinsi Jawa 
Persyaratan prosedural Izin Lokasi terdapat dalam Permeneg Agraria/Kepala BPN No. 2 Tahun 1999 dan Permeneg Agraria/Kepala BPN No. 2 Tahun 1993 tentang Tata Cara Memperoleh Izin Lokasi dan Hak Atas Tanah Dalam Rangka Penanaman Modal (Permeneg Agraria/ Kepala BPN No. 2 Tahun 1993).

Bertumpu pada berbagai peraturan perundang-undangan bidang perizinan dapat disarikan persyaratan prosedural Izin HO, Izin Usaha Industri, IPLM dan Izin Lokasi dalam tabel di bawah ini:

\section{Persyaratan Prosedural Izin HO, Izin Usaha Industri, Izin Pembuangan Limbah Ke Media Lingkungan dan Izin Lokasi}



Tabel. 2

Timur, Keputusan Menteri Perindustrian Tentang Analisis Mengenai Dampak Lingkungan (Amdal), Surabaya, t.th. dan Keputusan Menteri Negara Penggerak Dana Investasi/Ketua BKPM No. 126/I/Industri/1995 tentang Pemberian Izin Usaha Industri. 
Dari persyaratan prosedural perizinan lingkungan dapat diketahui tentang penanggung jawab instalasi. Melalui persyaratan prosedural terdapat proyeksi dan antisipasi perencanaan yang dilakukan instalasi industri dalam mengendalikan pencemaran lingkungan. Persyaratan prosedural merupakan langkah awal bagi instansi yang berwenang menerbitkan “izin lingkungan” untuk menetapkan elemen persyaratan substansial yang wajib ditaati pemegang izin dalam menjalankan roda perusahaannya dalam memberikan perlindungan hukum terhadap lingkungan.

\section{Persyaratan Substansial Izin HO, Izin} Usaha Industri, Izin Pembuangan Limbah ke Media Lingkungan (IPLM) dan Izin Lokasi

Persyaratan substansial Izin HO dapat ditemukan pada Pasal 6 dan 7 HO yang menekankan bahwa Izin HO diberikan dengan dasar pertimbangan instalasi yang didirikan tidak menimbulkan "gevaar" (bahaya), "schade" (kerusakan) dan "hinder” (gangguan) terhadap lingkungan:

\section{Artikel 6 HO:}

a. Weigering van een vergunning geschiedt bij met redenen omkleed besluit.

b. Tot de weigering kunnen alleen leiden:

$i$. de voorschriften van een verordening als bedoeld in de artikelen 2 en 3.

ii. De bezwaren ontleend aan vrees voor:

7. gevaar;

8. schade aan eigendommen, bedrijven of de gezondheid;

9. hinder van ernstigen aard, waartoe behoort:

1. het ter bewoning ongeschikt of minder geschikt maken van woonhuizen of gedeelten van woonhuizen, het belemmeren van het gebruik van scholen of van lokalen en gebouwen bestemd tot zieken verpleging of tot uitoefening van den openbaren eeredienst, binnen een kring van tweehondered meter van het gebouw of lokaal ler inrichting gelegen; ieder overeenkomstig de bestemming, welke het gebouw of lokaal, tijdens het verzoek werd gedaan, had;

2. het verspreiden van vuil of van walgelijke uitdampingen of geuren;

(3) Vrees voor mededinging in eenig bedrijf, door belanghebbenden geuit, kan geen reden tot weigering zijn. $^{12}$

Artikel $7 \mathrm{HO}$ :

Indien door het stellen van voorwaarden aan het bezwaar van gevaar, schade of hinder kan worden

${ }^{12}$ Terjemahan bebas Pasal 6 HO: (1) Penolakan suatu izin dilakukan dengan surat keputusan yang memuat alasan-alasannya. (2) Alasan yang dapat menyebabkan penolakan hanyalah: I. ketentuan peraturan sebagaimana dimaksud dalam Pasal 2 dan 3, II. Keberatan-keberatan yang dikarenakan khawatir akan terjadinya: a. bahaya, b. kerugian pada milik, perusahaan atau kesehatan, c. gangguan yang berat, termasuk: 1. sesuatu hal yang menyebabkan rumah kediaman atau bagiannya menjadi tidak dapat atau kurang baik untuk didiami (dihuni), hal merintangi pemakaian sekolah-skolah atau bilik-bilik dan bangunan-bangunan yang dipergunakan untuk perawatan orang sakit atau untuk menjalankan ibadah umum, yang terletak dalam lingkungan dua ratus meter dari bangunan atau ruangan instalasi itu, masing-masing menurut peruntukan bangunan atau bilik tempat kerja tersebut yang menyengat. (3) Kekhawatiran persaingan dalam suatu perusahaan, yang diketengahkan oleh para pihak yang berkepentingan, tidak dapat menjadi alasan penolakan izin. Bandingkan dengan John Salindeho, op.cit., h. 166-167. 
tegemoetkomen, wordtdevergunning voorwaardelijk verleend. ${ }^{13}$

Dalam konteks pengelolaan lingkungan hidup terdapat kewajiban pemegang Izin HO untuk mencegah terjadinya bahaya, kerusakan atau gangguan terhadap lingkungan akibat beroperasinya instalasi industri.

Persyaratan substansial Izin Usaha Industri dalam pengelolaan lingkungan hidup tercermin pada Pasal 21 ayat (1) UU Perindustrian dan Pasal 10 ayat (3) PP No. 13 Tahun 1995: melaksanakan upaya melestarikanfungsilingkungan(lingkungan) dan larangan untuk melanggar baku mutu lingkungan (baku mutu lingkungan ambien maupun baku mutu emisi).

Pasal 20 UUPLH yang mengatur IPLM tidak menuangkan persyaratan substansial. Namun, Pasal 18 ayat (3) UUPLH memberikan arahan bahwa IPLM harus mencantumkan "kewajiban untuk melakukan upaya pengendalian dampak lingkungan".

Dalam Pasal 8 ayat (3) Permeneg Agraria/Kepala BPN No. 2 Tahun 1999 diformulasikan persyaratan substansial Izin Lokasi: menghormati kepentingan pihak lain yang tanahnya belum dibebaskan, tidak mengurangi aksesibilitas publik, dan menjaga kepentingan umum.

Persyaratan substansial Izin HO, Izin Usaha Industri, IPLM dan Izin Lokasi berdasarkan peraturan perundang-undangan

\footnotetext{
13 Terjemahan bebas Pasal 7 HO adalah: Apabila dengan persyaratan-persyaratan dapat diupayakan hilangnya keberatan tentang bahaya, kerusakan atau gangguan, maka izin itu diberikan dengan syarat”. Lihat Ibid., h. 167.
}

yang berlaku dapat dituangkan dalam Tabel 9. Kesempurnaan penuangan persyaratan substansial dalam "perizinan lingkungan" menentukan secara signifikan efektivitas pengelolaan lingkungan hidup sehubungan dengan beroperasinya instalasi industri. Perumusan persyaratan substansial memiliki implikasi-korelatif terhadap komponen dasar persyaratan evaluatif perizinan lingkungan dalam rangka pengelolaan lingkungan hidup yang dilakukan oleh suatu korporasi (badan hukum). 
Persyaratan Substansial Izin HO, Izin Usaha Industri, Izin Pembuangan Limbah ke Media Lingkungan dan Izin Lokasi

\begin{tabular}{|c|c|c|c|}
\hline IZIN HO & $\begin{array}{l}\text { IZIN USAHA INDUSTRI } \\
\text { (IUI) }\end{array}$ & $\begin{array}{l}\text { IZIN PEMBUANGAN LIMBAH KE MEDIA } \\
\text { LINGKUNGAN } \\
\text { (IPLM) }\end{array}$ & IZIN LOKASI \\
\hline $\begin{array}{l}\text { Mencegah } \\
\text { terjadinya: } \\
\text { bahaya, } \\
\text { kerusakan, } \\
\text { dan gangguan } \\
\text { terhadap } \\
\text { lingkungan } \\
\text { (berupa } \\
\text { penyebaran } \\
\text { kotoran, } \\
\text { penguapan atau } \\
\text { kebauan akibat } \\
\text { dari beroperasi- } \\
\text { nya instalasi } \\
\text { industri) }\end{array}$ & $\begin{array}{l}\text { Melaksanakan upaya } \\
\text { keseimbangan dan } \\
\text { kelestarian (fungsi) sumber } \\
\text { daya alam } \\
\text { (SDA). } \\
\text { Mencegah timbulnya } \\
\text { pencemaran dan perusaka } \\
\text { lingkungan (tanah, air } \\
\text { maupun lingkungan) } \\
\text { Mentaati ketentuan baku } \\
\text { mutu lingkungan (BML) } \\
\text { Melaksanakan upaya } \\
\text { keamanan dan keselamatan } \\
\text { alat, bahan baku dan } \\
\text { bahan penolong, proses } \\
\text { produksi serta } \\
\text { berbagai hasil produksinya }\end{array}$ & $\begin{array}{l}\text { Melakukan upaya } \\
\text { pengendalian dampak } \\
\text { lingkungan (lingkungan) }\end{array}$ & $\begin{array}{l}\text { Menghormati } \\
\text { kepentingan pihak lain } \\
\text { yang tanahnya } \\
\text { belum dibebaskan } \\
\text { Tidak mengurangi } \\
\text { aksesibilitas masyarakat } \\
\text { sekitar lokasi } \\
\text { Menjaga dan } \\
\text { melindungi kepentingan } \\
\text { umum }\end{array}$ \\
\hline
\end{tabular}

Tabel. 3

Persyaratan Evaluatif Izin HO, Izin

Usaha Industri, Izin Pembuangan

Limbah ke Media Lingkungan (IPLM) dan Izin Lokasi

DalamHO tidak diketemukan ketentuan mengenai persyaratan evaluatif Izin HO. Pengaturan Izin HO tidak mewajibkan kepada pemegangnya untuk melakukan pemantauan ("monitoring”) dan pelaporan ("reporting") terhadap pelaksanaan persyaratan substansial Izin HO.

Persyaratan evaluatif Izin Usaha Industri terdapat dalam Pasal 14 ayat (1) UU Perindustrian dan Pasal 10 PP No. 13 Tahun 1995 yang mengatur tentang kewajiban pihak industri untuk menyampaikan "informasi industri" secara periodik "mengenai kegiatan dan hasil produksinya". Namun, peraturan perundang-undangan Izin Usaha Industri tidak memuat keharusan bagi industri untuk mempublikasikan "informasi industri" kepada publik. Informasi industri terkesan (hanya) bersifat internal-birokratik.

Pasal 9 Permenag Agraria/Kepala BPN No. 2 Tahun 1999 menetapkan persyaratan evaluatif Izin Lokasi: "menyampaikan secara periodik tentang perolehan tanah dan pelaksanaan penggunaan tanah kepada Kepala Kantor Pertanahan". Pelaporan kegiatan pemegang Izin Lokasi kepada Kepala Kantor Pertanahan merupakan tindakan yang "salah alamat". Wewenang 
menerbitkan Izin Lokasi menurut Pasal 6 ayat (2) Permenag Agraria/Kepala BPN No. 2 Tahun 1999 berada di Bupati/Walikota atau Gubernur untuk wilayah DKI Jakarta, bukan di Kepala Kantor Pertanahan.

Jelaslah bahwa tidak semua peraturan perundang-undangan "izin lingkungan" merumuskan persyaratan evaluatif. Bahkan formulasi hukum persyaratan evaluatif "izin lingkungan" sarat problematika seperti tampak pada tabel di bawah ini:

Persyaratan Evaluatif Izin HO, Izin Usaha Industri, Izin Pembuangan Limbah ke Media Lingkungan dan Izin Lokasi

\begin{tabular}{|c|c|c|c|}
\hline IZIN HO & $\begin{array}{l}\text { IZIN USAHA } \\
\text { INDUSTRI } \\
\text { (IUI) }\end{array}$ & $\begin{array}{l}\text { IZIN PEMBUANGAN LIMBAH KE } \\
\text { MEDIA LINGKUNGAN } \\
\text { (IPLM) }\end{array}$ & IZIN LOKASI \\
\hline Tidak ada & $\begin{array}{l}\text { Menyampaikan } \\
\text { informasi industri } \\
\text { secara periodik atau } \\
\text { berkala kepada instansi } \\
\text { yang berwenang } \\
\text { menerbitkan Izin } \\
\text { Usaha Industri (IUI) } \\
\text { mengenai kegiatan dan } \\
\text { hasil industrinya }\end{array}$ & Tidak ada & $\begin{array}{l}\text { Menyampaikan } \\
\text { laporan secara } \\
\text { periodik tentang } \\
\text { perolehan tanah } \\
\text { dan penggunaan } \\
\text { tanah }\end{array}$ \\
\hline
\end{tabular}

Tabel. 4

\section{Pengaturan perizinan lingkungan} dan totalitas penuangan persyaratannya ternyata kurang efektif sebagai instrumen hukum pengelolaan lingkungan hidup. Berdasarkan Pasal 22 PP PPU: semua jenis perizinan lingkungan (Izin HO, Izin Usaha Industri, IPLM dan Izin Lokasi) seyogianya merumuskan secara tepat persyaratan perizinan yang kondusif bagi upaya pengelolaan lingkungan hidup.

\section{Penutup: Persyaratan Perizinan} Lingkungan yang Kondusif Bagi Upaya Pengelolaan Lingkungan Hidup di Indonesia

Berkenaan dengan persyaratan perizinan lingkungan yang memiliki arti penting bagi pengelolaan lingkungan hidup, dikemukakan pula aturan di Amerika Serikat, Belanda, Jepang dan Singapura sebagai bahan perbandingan. CAA Amerika Serikat menuangkan persyaratan perizinan lingkungan bagi aktivitas pengelolaan lingkungan hidup pada ketentuan tentang "permit programs" (Pasal 502) dan "permit conditions" (Pasal 504). ${ }^{14}$

Belanda mengatur persyaratan (prosedural, substansial dan evaluatif) perizinan lingkungan secara khusus dalam Environmental Management Establishment and Licences Decree. Dokumen hukum Environmental Management Establishment

${ }^{14}$ EPA United States Environmental Protection Agency, Regulations, http://www.epa.gov/oar/caa/ caa502.txt, 11/12/2000. M. Granger Morgan, "Risk Analysis and Management", Scientific American, July 1993, h. 32-41. 
and Licences Decree Pemerintah Belanda ini memuat persyaratan perizinan lingkungan sehubungan dengan pendirian dan pengoperasian suatu instalasi ("establishment"). ${ }^{15}$

APCL Jepang mengatur persyaratan perizinan lingkungan untuk mengendalikan pencemaran lingkungan pada Pasal 18-18.3 APCL tentang "Report of the Establishment of Particulates Discharging Facility. ${ }^{16}$ CAA Singapura merumuskan persyaratan perizinan lingkungan yang relevan dengan pengelolaan lingkungan hidup dalam Section 15 mengenai: "Power of Minister to Prohibit Use of Combustible Materials, Fuel Burning Equipment or Industrial Plant in Certain Area". ${ }^{17}$

\section{Persyaratan Perizinan Lingkungan Bidang Pengelolaan lingkungan hidup}

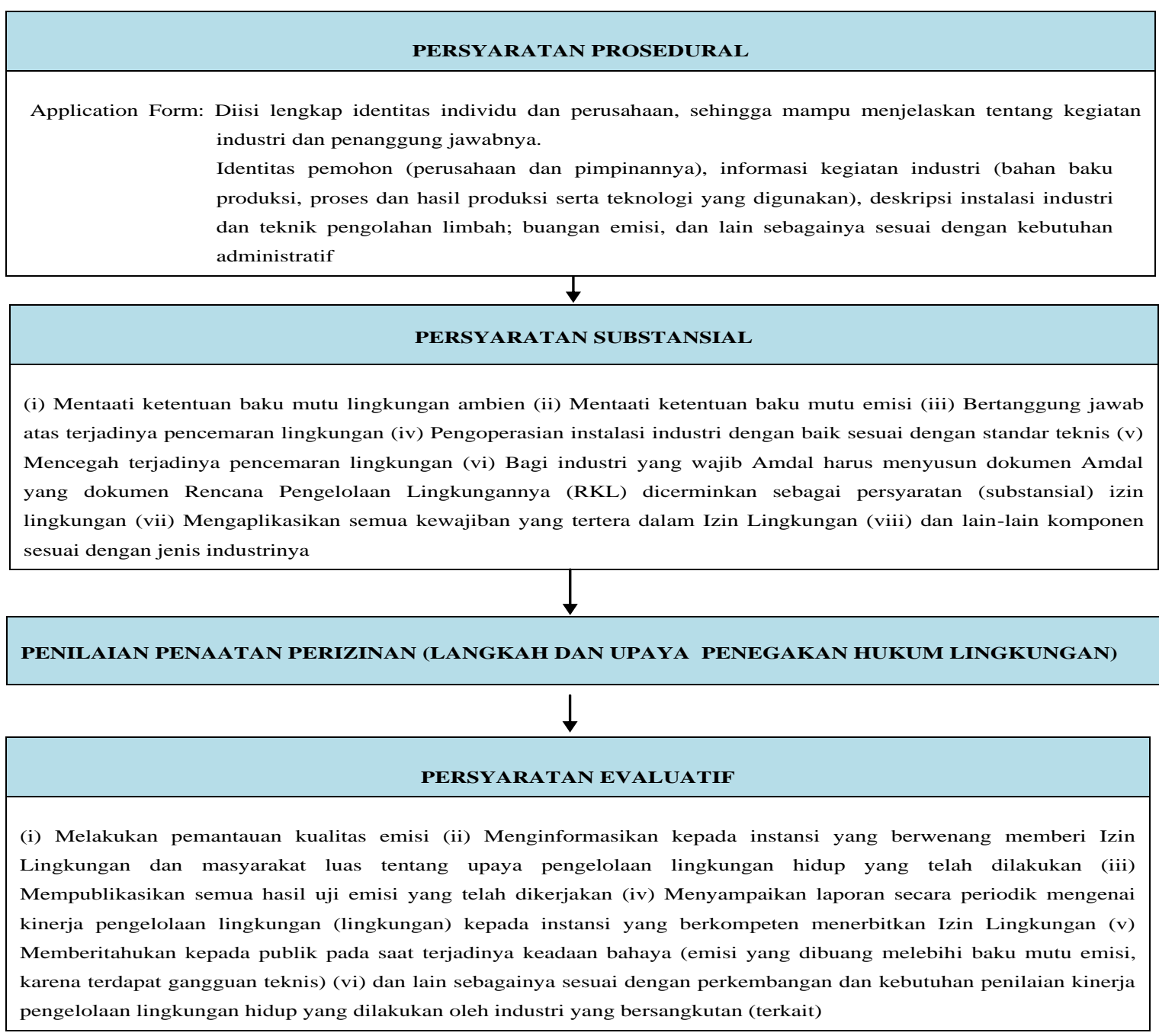

${ }^{15}$ Ministry of Housing, Spatial Planning and the Environment Directorate-General for Environmental Protection Directorate for General Policy/Code 660, Environmental Management Establishments and Licences Decree, The Hague, The Netherlands, 1998, h. 3-4.

${ }^{16}$ Environment Agency, Environmental Laws and Regulations in Japan (II) Air, Japan, t.th., h. 17-18.

${ }^{17}$ Lye Lin Heng, op.cit., h. 5-6. Sebagai bahan perbandingan adalah United Nations Development Programme (UNDP), United Nations Environment Programme (UNEP) and the World Bank, Global Environment Facility: Independent Evaluation of the Pilot Phase, The World Bank - The International Bank for Reconstruction and Development, Washington, D.C., USA, 1995. 
Bertolak dari kajian teoritik dan hukum positif di atas dapat dikemukakan bahwa persyaratan perizinan lingkungan yang kondusif bagi upaya pengelolaan lingkungan hidup pada dasarnya adalah sebagaimana tercantum dalam Skema di atas:

Ini semua penting artinya setelah adanya Undang-undang No. 32 Tahun 2009 tentang Perlindungan dan Pengelolaan Lingkungan Hidup (UU PPLH). Pasal 1 angka 31 UU PPLH menyatakan bahwa Izin lingkungan adalah izin yang diberikan kepada setiap orang yang melakukan usaha dan/atau kegiatan yang wajib amdal atau UKL-UPL dalam rangka perlindungan dan pengelolaan lingkungan hidup sebagai prasyarat untuk memperoleh izin usaha dan/atau kegiatan. Pasal 36 UU PPLH mengatur: Setiap usaha dan/atau kegiatan yang wajib memiliki amdal atau UKL-UPL wajib memiliki izin lingkungan. Izin lingkungan sebagaimana dimaksud diterbitkan berdasarkan keputusan kelayakan lingkungan hidup sebagaimana dimaksud dalam Pasal 31 atau rekomendasi UKL-UPL. Izin lingkungan wajib mencantumkan persyaratan yang dimuat dalam keputusan kelayakan lingkungan hidup atau rekomendasi UKL-UPL. Izin lingkungan diterbitkan oleh Menteri, gubernur, atau bupati/walikota sesuai dengan kewenangannya. Ditegaskan pula: Menteri, gubernur, atau bupati/ walikota sesuai dengan kewenangannya wajib menolak permohonan izin lingkungan apabila permohonan izin tidak dilengkapi dengan amdal atau UKL-UPL. Izin lingkungan dapat dibatalkan apabila: (i) persyaratan yang diajukan dalam permohonan izin mengandung cacat hukum, kekeliruan, penyalahgunaan, serta ketidakbenaran dan/atau pemalsuan data, dokumen, dan/ atau informasi; (ii) penerbitannya tanpa memenuhi syarat sebagaimana tercantum dalam keputusan komisi tentang kelayakan lingkungan hidup atau rekomendasi UKLUPL; atau (iii) kewajiban yang ditetapkan dalam dokumen amdal atau UKL-UPL tidak dilaksanakan oleh penanggung jawab usaha dan/atau kegiatan

Penentuan persyaratan perizinan lingkungan (prosedural-substansialevaluatif) dalam rangka pengelolaan lingkungan hidup merupakan rangkaian yang mutlak untuk dilaksanakan dan ditegakkan. Dari persyaratan prosedural dan substansial dapat digambarkan kualitas "individualinstitusional" pengelolaan lingkungan hidup yang akan dilakukan perusahaan. Persyaratan evaluatif perizinan lingkungan harus dirumuskan secara komprehensif dengan menguraikannya dalam komponen administratif yang dapat dinilai secara yuridis.

\section{DAFTAR BACAAN}

Addink, G.H., Publications About the Implementation and Enforcement of the Climate Change Convention and the Kyoto Protocol, Utrecht University, The Netherlands, 1998.

------, General Principles of Good Governance Under GALA, Utrecht University, Utrecht, 2001. 
------, Environmental Law in a Comparative Perspective: National, European and International Law: Literature, Utrecht University, Utrecht, 2002.

------, Norms and Enforcement of Climate Change Convention, Utrecht University, Utrecht, t.th.

Beroya, Mary Antonette A., Mengenal Lingkungan Hidup: Pedoman Untuk Memperkuat Rakyat, Yakoma-PGI, Jakarta, 2000.

Biezeveld, G.A., Duurzame Milieuwetgeving, Boom Juridische Uitgevers, Den Haag, 2002.

Blomberg, A.B., Integrale Handhaving van Milieurecht, Boom Juridische Uitgevers, de Vrije Universiteit te Amsterdam, 2000.

Boer, Ben, (ed.), Environmental Law in the South Pacific, IUCN Environmental Law Centre, United Kingdom, 1996

------, et al., International Environmental Law in the Asia Pacific, Kluwer Law International, 1998.

Boon, Foo Kim, Lye Lin Heng and Koh Kheng Lian, Environmental Protection: The Legal Framework, IUCN/APCEL/UNEP Programme, Singapore, 1997.

Cane, Peter, An Introduction to Administrative Law, Clarendon Press, Oxford, 2001.

Dix, H.M., Environmental Pollution: Atmosphere, Land, Water, and Noise, John Wiley \& Sons Ltd., Chichester, 1981.

Drupsteen, Th.G., et al., De Toekomst van de Wet Milieubeheer, Rijksuniversiteit Leiden, W.E.J. Tjeenk Willink, Deventer, 1998.
Eade, John, (ed.), Living the Global City, Routledge, London, 1997.

Emond, D. Paul, Environmental Law: Resource Materials for the Study of Environmental Law in Indonesia and Canada, EMDI, Halifax and Jakarta, 1990.

Environment Agency Japan, Environmental Laws and Regulations in Japan, Japan, 1984.

------, Texbook for Training Course in Environmental Engineering (Air Pollution Control), Japan, 1997.

Euroconfidentiel S.A., The Rome, Maastricht and Amterdam Treaties, Belgium, 1999.

European Commission, The European Union and the Environment, Luxembourg, 1997.

------, The Customs Policy of the European Union, Luxembourg, 1999

Faure, Michael and Gunter Heine, Environmental Criminal Law in The European Union, METRO Institute for Transnational Legal Research, Maastricht, The Netherlands, 1998.

Foque', R. en S. Gutwirth (red.), Vraagstukken van Milieurechtelijke Begripsvorming, Gouda Quint, Erasmus Universiteit Rotterdam, 2000.

Gilks, Mark, Interim Transport Plan 2000/2001, Environmental Department, London, 2001.

Hoekema, A.J., et al., Integraal Bestuur, Amsterdam University Press, Amsterdam, 1998.

Kiss, Alexandre and Dinah Shelton, Manual of European Environmental 
Law, Grotius Publication Cambridge University Press, Cambridge, 1997.

Lee, C.C., Dictionary of Environmental Legal Terms, McGraw-Hill, New York, USA, 1997.

Moussis, Nicholas, Guide to EU Policies, European Study Service, Belgium, 2000.

Mukono, H.J., Pencemaran Udara dan Pengaruhnya Terhadap Gangguan Saluran Pernapasan, Airlangga University Press, Surabaya, 1997.

------, Prinsip Dasar Kesehatan Lingkungan, Airlangga University Press, Surabaya, 2000 .

Murdiyarso, Daniel, Sepuluh Tahun Perjalanan Negosiasi Konvensi Perubahan Iklim, Penerbit Buku Kompas, Jakarta, 2003.

------, Protokol Kyoto: Implikasinya Bagi Negara Berkembang, Penerbit Buku Kompas, Jakarta, 2003.

------, CDM: Mekanisme Pembangunan Bersih, Penerbit Buku Kompas, Jakarta, 2003.

NAA, Environmental Report' 98: Creating an Eco-Airport, Vol. 3 January 1999.

Portney, Paul R. and Robert N. Stavins, Public Policies for Environmental Protection, Resources for the Future, Washington, D.C., 2000.

\section{Proyek Pembinaan Teknis Yustisial} Mahkamah Agung RI, Undangundang Nomor 23 Tahun 1997 tentang Pengelolaan Lingkungan Hidup dan Permasalahannya, Jakarta, 1998.
Rangkuti,SitiSundari, Hukum Lingkungan dan Kebijaksanaan Lingkungan Nasional, Edisi Kedua, Airlangga University Press, Surabaya, 2000.

Susilo, F.X. Endro, Suparto Wijoyo and Ibrahim, An Overview of Indonesian Environmental Law and Comparative Aspects, Faculty of Law, Utrecht University, The Netherlands, 2002.

Syarif, La Ode Muhamad, The Implementation of International Responsibilities for Atmospheric Pollution, LEAD Indonesia-ICEL, Jakarta, 2001.

United Nations, The Earth Charter, October, 2002.

Wood, Christopher, Environmental Impact Assessment: A Comparative Review, Logman Group Limited, England, 1996

\section{Internet Sites}

http://www.epa.gov/oar/caa/contents.html

http://europa.eu.int/comm/dg01

http://europa.eu.int/eurostat.html

http://europa.eu.int/euro

http://www.tempointeraktif.com

http://www.tempointeractive.com

http://www.kompas.com 